\title{
"Easing the Shortage" in China: An Economic View on the Early Childhood Education and Care
}

\author{
Lei GUO ${ }^{1, a,{ }^{*}}$, Run-Yu LI ${ }^{2, b}$ and Hong LIU ${ }^{3, c}$ \\ ${ }^{1,2}$ School of Public Finance and Taxation, Shandong University of Finance and Economics, Jinan, \\ China; \\ ${ }^{3}$ Department of Education, National Pilot Reform Dsitrict of Preschool Education (Junan), China. \\ aguolei@sdufe.edu.cn, brunyu091@sina.com, cjnjtjxqjy@163.com \\ ${ }^{*}$ Corresponding author
}

Keywords: Preshcool Education, Early Childhood Intervention, Mechanism Design, Supply Side.

\begin{abstract}
The mismatch of the demand side and the suppy side in the Early Childhood Education and Care (ECEC) sector has been a recurring pattern in China for a long time. As another baby boom is looming on the horizon, "Easing the Shortage" is an urgent need. By describing the ratio of the capital investment in China, the structure within the government eduational expeditures, and the ratio of public-private facilities, this article makes a different argument that the ideas of the local officials, the inter-governmental relationships and the incentive mechanism design are the driving force of the development. The countermeasures are the more aggressive intervention policies, a scientific mechanism design, and a regulatory reform of the private sector in ECEC.
\end{abstract}

\section{Introduction}

In recent decades, the Early Childhood Education and Care (ECEC) has become a central issue for the governments in many developd countries[1]. However, the government investment in early childhood service sector is not matched with the China's lofty aim - "a stong nation of education". Several child-abuse incidents resonated far and wide in 2017 and private kidergartens were accused by the national media more than the previous years. On the surface these events definitely happened in the private organzations, but from another point of view, they underscored the scarcity of the public facilities.

\section{The underinvest in preschool programs in China}

China has always been in a position that the governmental expenditure on investment in people below the average among the world. The 2000 Nobel laureate James Heckman once noted "In 1995, China, at all levels of government, spent about $2.5 \%$ of its GDP on investment in schooling. At the same time, roughly 30\% of its GDP was devoted to physical investment. In the United States, those figures were $5.4 \%$ and 17\%, respectively. In South Korea, they were 3.7\% and 30\%.”[2] The underinvestment in human capital means an imbalanced policy that seeks to improve productivity by encouraging investment in physical capital in China. But such a strategy would not sustainable, and will lower the rate of return of all kinds of capital investment eventually.

The globle financial crisis broke out in 2008 devitalized the economy of China and retarded the speed of a more balanced investment strategy. The trend of underinvestment in human capital and overinvestment in physical capital seems unchanged in the nearset decade. Fig. 1 shows the relation between China's physical capital investment (PCI) and the human capital investment (HCI). Although China spent about 4\% of its GDP on investment in education in 2012, it takes 17 years to achieve the legal target. 


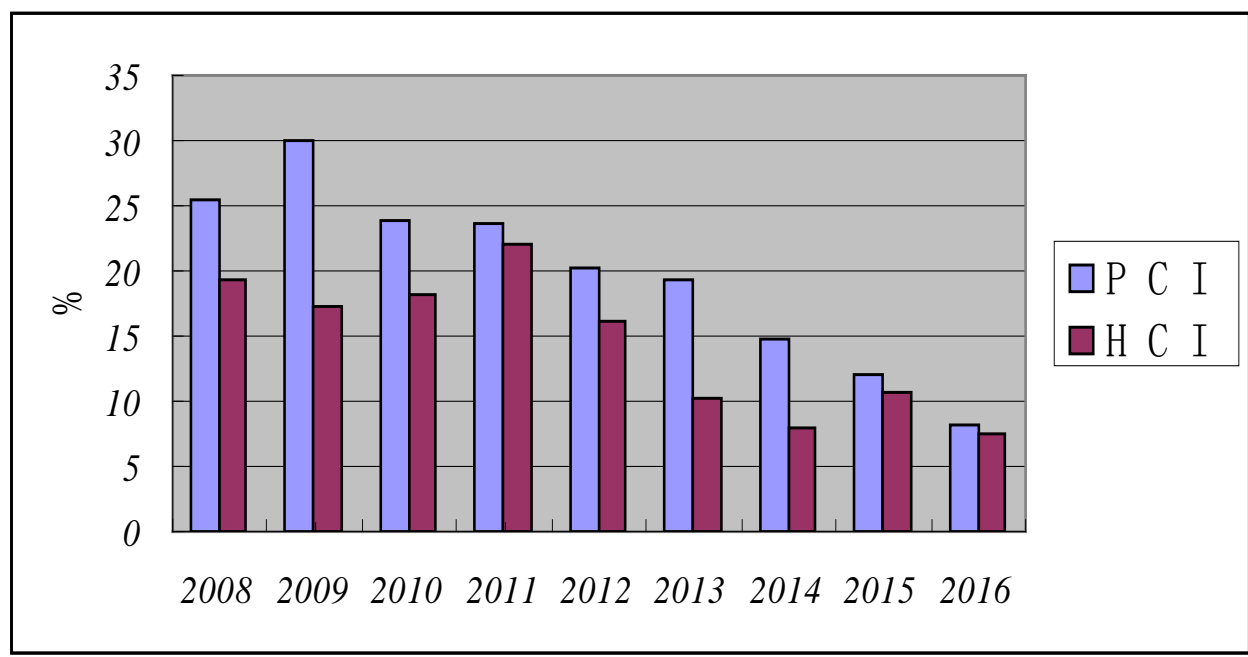

Source: Bulletin of Statistics China's National Bureau of Statistics; China educational finance statistical yearbook (2008-2016)

Fig. 1: PCI vs. HCI in China (2008-2016)

When we the break the blackbox of the educational expenditure, another deformation can be find in the interior structure. In 2010, when the "Outline of China's National Plan for Medium and Long-term Education Reform and Development ( 2010-2020) " issued, China's ECEC appropriation was below $0.05 \%$ GDP, contrasted with $0.36 \%$ GDP of the United States and the means of European Union[3]. If we take the Heckman curve (Fig. 2) as a benchmark, there should be even higher proportion for this field because of the higher rate of return of the investiment in the early childhood programs. "At current levels of resources, society overinvests in remedial skill investments at later ages and underinvests in the early years."[4]

What makes a lager scale of investment in the ECEC sector an ugent task is the population changes. About 5 years ago, China began to allow couples to have a second baby if either parent is an only child. At the end of 2015, the demographic policy in China became that all are the eligible couples to have a second baby. It is clear that the capacity of the early childhood service will directly face the challenges raised by the ongoing population change.

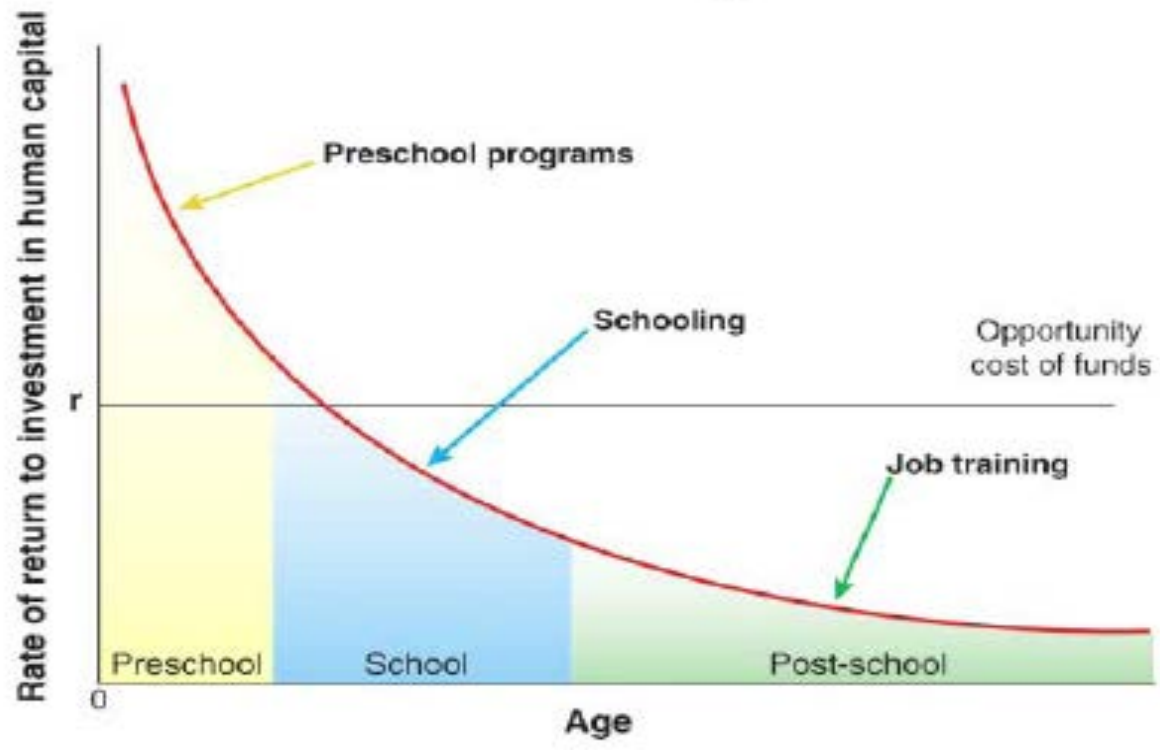

Source: J. Heckman 2006

Fig. 2 the Heckman curve 


\section{Some of the reasons}

"A central issue for OECD governments in relation to early childhood funding is not whether to invest, but how much and at what level" [1]. But why the investment in China's ECEC sevice maintains a low level and has been keeping underinvest for a long time? A growing economic literature on the public goods and services as well as human capital theory has substantially improved our understanding of how these happen.

One reason for the deformation in China is the local officials' blurred image about the ECEC. Early childhood is a period of profound advances in reasoning, language acquisition, and problem solving. Participants in early intervention programs score systematically better on a wide range of variables measuring educational achievements and high school graduation rates and, later in life, employment rates, monthly earnings, welfare receipt status, and crime rates[5]. Short-term gains from participation in preschool on early cognitive skills and school readiness are well documented[6]. Increasingly, studies are also finding long-term effects of early childhood program participation on health, educational attainment, risky behaviors, and earnings[7]. However, if the importance of these programs receives little focus by the educational policy makers, the rating of budget priority of ECEC will never go to top.

Another reason is that the incentive non-compatibility in the public sector contributes to the problem. Originated by Qian and Roland[8], an interesting argument emerged that the fiscal system under fiscal decentralization with Chinese style would affect the provision of public goods and services. For example, an empirical study finds that fiscal decentralization reduces the quality of primary education significantly and remarkably[9]; by constructing educational fiscal decentralization indicators and based on provincial panel data from 1998 to 2010, another empirical study finds that excessive fical decentralization in basic education with the yardstick competition for higher performance evaluation in nine-year compulsory education would induce local governments' inclination to emphasize primary education investment and neglecting pre-school education investment[10]. All these things are contributors to a mismatch between the high rate of return of the preschool programs and the underinvestment in the ECEC sector in China[11].

\section{Suggestions}

The New Era of China may be aptly labeled the era of human capital more than any other period in history. Economic literature on human capital gives some important implications for public policy. In our opinions four points are worth commenting.

The initial one is the suggestion for strengthening the connection between science and policy. Advanced theory should translate into good public policy and empirical research should convince public officials to alter their policy preferences. Extensive literatures in economics, neuroscience, and psychology all conclude that early childhood investments can benefit children, parents, and society. "When an idea from early childhood education research, such as the critical importance of early intervention, enters the public domain, that is a victory for science”. [12]

A second related aspect deals with the the theory of incentive compatibility. A scientific mechanism design of incentive will yield twice the result with half the effort. In fact, the imbalanced investment policy between physical capital and human capital reflects the incentive distortion of performance, as is discussed by Qian and Roland in 1998[8], also reappearing in FU[9] and some of the educational empirical studies[10]. We believe that the incentive non-compatibility will be corrected eventually, because a fast speed of GDP growth will not be a promotion short cut for the local officials, especially after the 19th National Congress of the Communist Party of China in 2017.

Third, reform the fiscal system, including optimize the combination of inter-government responsibilities and enlarge federal and provincial "cost sharing ratio", for the local governments undertook too more responsibilities in China. An American scholar states that "values regarding equity and fairness imply that support for child care should occur primarily at the federal level, 
rather than at the state or local levels"[13]. However the China's situation is "the more public kindergartens exist, the larger ratio of cost sharing the local government would undertake"[14]. So it is no surprising that the scarcity of the public ECEC facilities is commonplace in the underdeveloped areas. In the low income areas, parents with lower average lifetime earnings tend to have children earlier in their careers, and they also tend to have more children[15]. So the fiscal burdens are heavier in these areas than the developed cities in the near future given the population changes. "Equity demands that access to public goods and standards of living should not be completely dependent on where one lives, given the wide variation in states' needs, resources, and costs of providing services"[13].

Last but not the least, there should be some incentives to enlarge the scale of private investment. The New Public Management movement holds the view that public programs should involve private providers and producers so that a public-private-partnership will be achieved. "Relying on any single institutional model generates far less information about alternatives and consequences than allowing multiple institutions to exist side-by-side" [16]. To expand the private investment, the mechanism should abolish the "price-cap regulation" and carry out the "rate-of-return regulation", for the "A-J Effect”[17] will lead the investors put more money into the ECEC sector.

\section{Acknowledgement}

This research was financially supported by the Shandong Social Science Foundation [15CJJJ14]. The views expressed herein are those of the authors and not necessarily those of the Shandong Social Science Foundation.

\section{References}

[1] OECD, Starting Strong, OECD Press, Paris, 2006.

[2] J. J. Heckman, China’s human capital investment, China Economic Review. 2005, 16(1): 50-70.

[3] OECD, Education at a Glance 2013: OECD Indicators, OECD Press, Paris, 2013.

[4] J. J. Heckman, Skill formation and the economics of investing in disadvantaged children, Science. 2006, 312: 1900-1902.

[5] P. Vanhuysse, The new political economy of skill formation, Public Administration Review. 2008, 68(5): 955-959.

[6] J. L. García, J. J. Heckman, E. L. Duncan, M. J. Prados, Quantifying the Life-cycle Benefits of a Prototypical Early Childhood Program, NBER Working Paper (2017). No. 23479.

[7] F. A. Campbell, G. Conti, J. J. Heckman, S. H. Moon, R. Pinto, E. Pungello, Y. Pan, Early childhood investments substantially boost adult health. Science. 2014, 343: 1478-1485.

[8] Qian, Yingyi, Roland, Gerard, Federalism and the soft budget constraint, The American Economic Review. 1998, 88(5): 1143- 1162.

[9] FU Yong, Fiscal decentralization, governance and non-economic public goods provision[J]. Economic Research. 2010(8): 4-15.

[10]BAI Tan, ZHOU Dequn, WANG Shuijuan. Relationship between fiscal decentralization in education and distortion of public expenditure composition in Basic Education, Tsinghua Journal of education. 2015, 36(2): 53-62.

[11] GUO Lei, On the restructure of the educational expenditure, Review of Economic Research. 2015, (2): 65-69.

[12] Gormley Jr. From science to policy in early childhood education, Science. 2011, 333: 978-81. 
[13] A. J. Cohen, A brief history of federal financing for child care in the United States, The Future of Children. 1996, 6(2): 26-40.

[14] ZHANG Xue, Influence factors of cost sharing of preschool education of county-level governments, Education Research Monthly. 2016(9): 53-63.

[15] G. S. Becker, Human Capital: A Theoretical and Empirical Analysis, with Special Reference to Education, third ed., Columbia University Press, New York, 1993: 17, 21.

[16] E. Ostrom, G. Davis, Nonprofit organizations as alternatives and complements in a mixed Economy, in: D. C. Hammack and D. R. Young (Eds.), The Nonprofit Organizations in a Market Economy, Jossey-Bass Publishers, 1993, pp.23-56.

[17] H. Averch, L. Johnson, Behavior of the firm under regulatory constraint, The American Economic Review. 1962(52): 1052-1069. 